\title{
TEORI PERTUMBUHAN BASIS EKSPOR: PENERAPANNYA UNTUK PERTUMBUHAN REGIONAL DI KABUPATEN JEPARA
}

\author{
Shandy Jannifer Matitaputty \\ Universitas Katolik Soegijapranata \\ deta.matitaputty@gmail.com
}

\begin{abstract}
Jepara district is a district that was born from trading activities. This study intends to analyze the characteristics of Jepara regency economy associated with regional growth theory of export base and see a picture of the application of the theory of the growth of the export base in Jepara regency. This study uses a model export base analysis and sector analysis model base. The results showed the condition of Jepara regency trade balance deficit should be a concern if you want to implement a growth model export base. Community characteristics, expertise woodcarving hereditary, the ability to survive in times of crisis, as well as branding of furniture and handicraft carving that can actually be used as the power demand (exports).
\end{abstract}

Keywords: Regional Economic, Theories of Economic Growth, Export Base Model

\section{PENDAHULUAN}

Pertumbuhan ekonomi dalam skala nasional mencerminkan perkembangan ekonomi dari tahun ke tahun atas seluruh wilayah nasional. Dalam skala yang lebih sempit (skala regional) pertumbuhan ekonomi akan sangat tergantung pada karakteristik serta kemampuan suatu wilayah/region dalam mengelola wilayahnya. Menurut Sjafrizal (2008:86) perhatian terhadap pertumbuhan ekonomi daerah semakin meningkat di daerah otonomi daerah. Hal ini dapat dipahami, karena dalam era otonomi masingmasing daerah berlomba-lomba meningkatkan pertumbuhan ekonomi daerahnya guna meningkatkan kemakmuran masyarakatnya. Perbedaan pokok antara analisa pertumbuhan perekonomian nasional dan analisis pertumbuhan daerah adalah bahwa yang dititik beratkan dalam analisa pertumbuhan ekonomi regional adalah perpindahan faktor (Richardson, terjemahan Paul Sihotang, 1977).
Terdapat beberapa teori pembangunan dan pertumbuhan ekonomi regional, diantaranya: (1) Teori Basis Ekspor; (2) Teori Pertumbuhan Jalur Cepat; (3) Teori Pusat Pertumbuhan; (4) Teori Neoklasik; (5) Model Kumulatif Kausatif; dan (6) Model Interregional. Teori basis ekspor membagi sektor produksi yang terdapat di dalam suatu wilayah atas sektor basis (dasar) dan sektor nonbasis (service). Teori ini merupakan model yang paling sederhana dimana faktor penentu pertumbuhan ekonomi secara langsung sangat tergantung kepada permintaan akan barang dari daerah lain (diluar batas regional). Secara sederhana model ini menekankan pentingnya aliran uang masuk serta menekankan pada permintaan. Penggunaan sumber daya lokal termasuk tenaga kerja dan material (bahan) untuk memenuhi permintaan termasuk ekspor, akan mendorong meningkatnya aktivitas ekonomi, menciptakan kesempatan kerja dan memperbaiki kesejahteraan masyarakat. 
Pengenalan karakteristik suatu wilayah serta penerapan sistem perekonomian yang tepat akan mendorong percepatan pertumbuhan wilayah tersebut. Karakter teori basis ekspor akan tepat diterapkan pada wilayah/region yang pertumbuhan ekonominya didorong oleh permintaan akan barang/jasa terhadap wilayah tersebut. Kabupaten Jepara memiliki sistem perekonomian yang cukup terbuka. Hal tersebut dapat diidentfikasi dari kegiatan ekspor dan impor Kabupaten Jepara, kegiatan ekspor dan impor yang dimaksud adalah dalam pengertian regional.

\section{Tabel 1}

\section{PDRB Penggunaan Kabupaten Jepara Tahun} 2001 dan 2008 (Jutaan Rupiah)

\begin{tabular}{|l|r|r|}
\hline Keterangan & \multicolumn{1}{c|}{ Tahun 2001 } & \multicolumn{1}{c|}{ Tahun 2008 } \\
\hline Konsumsi (RT dan Pemerintah) & $2.478 .320,05$ & $6.682 .723,38$ \\
\hline $\begin{array}{l}\text { Investasi (PMTB + Perubahan } \\
\text { Stok) }\end{array}$ & $533.173,72$ & $1.594 .557,13$ \\
\hline Ekspor & $2.461 .557,08$ & $4.381 .659,44$ \\
\hline Impor & $1.907 .768,09$ & $5.203 .061,92$ \\
\hline PDRB Penggunaan & $3.565 .282,76$ & $7.455 .878,03$ \\
\hline
\end{tabular}

Sumber : Tabel I - O Kabupaten Jepara Tahun 2001 dan 2008, diolah.

$\begin{array}{llrl}\text { Tabel } 1 & \text { menunjukkan } & \text { komponen } \\ \text { penyusun PDRB } & \text { Penggunaan } & \text { Kabupaten }\end{array}$
Jepara yang diproksi dari tabel Input - Output (I - O) Kabupaten Jepara tahun 2001 dan 2008. Komponen ekspor dan impor memiliki angka yang cukup besar, sekalipun tidak sebesar konsumsi. Terjadi penurunan ekpor pada tahun 2008 bila dibanding tahun 2001 .

Salah satu model pertumbuhan ekonomi regional yang menekankan pentingnya aliran uang masuk dan menekankan pada permintaan adalah model pertumbuhan regional basis ekspor. Komponen permintaan terdiri dari permintaan: antara, rumah tangga, pemerintah, pembentukan modal tetap, stok serta ekspor.
Tabel 2

Komposisi Komponen Permintaan Total/

Regional

Kabupaten Jepara Tahun 2001 dan 2008

\begin{tabular}{|c|c|c|c|}
\hline \multirow{2}{*}{ KODE } & \multirow{2}{*}{$\begin{array}{c}\text { KOMPONEN } \\
\text { PERMINTAAN }\end{array}$} & \multicolumn{2}{|c|}{$\begin{array}{c}\text { RASIO INPUT ANTARA } \\
\text { (Presentase) }\end{array}$} \\
\cline { 3 - 4 } & & $\mathbf{2 0 0 1}$ & $\mathbf{2 0 0 8}$ \\
\hline 180 & Permintaan antara & 33,43 & 31,82 \\
\hline 301 & Permintaan rumah tangga & 23,18 & 30,02 \\
\hline 302 & Permintaan pemerintah & 4,08 & 5,11 \\
\hline 303 & Permintaan modal tetap & 6,32 & 6,54 \\
\hline 304 & Persediaan & 0,66 & 1,62 \\
\hline 305 & Ekspor & 32,33 & 24,90 \\
\hline 309 & Jumlah permintaan akhir & 66,57 & 68,18 \\
\hline
\end{tabular}

Sumber : Tabel I - O Kabupaten Jepara Tahun 2001 dan 2008, diolah.

Tabel 2 menunjukkan dari seluruh total permintaan pada tahun 2008, sekitar 31, 82 persen digunakan oleh sektor lainnya untuk proses produksi, kemudian dari permintaan akhir 24,90 persen digunakan untuk ekspor. Hal ini menunjukkan aktivitas ekonomi Kabupaten Jepara selain digerakkan oleh peningkatan konsumsi rumah tangga juga diimbangi oleh tingginya ekspor.

Nilai ekspor terbesar Kabupaten Jepara didominasi oleh sektor industri rumah perabot rumah tangga dari kayu senilai 1.630,07 milyar rupiah atau bila diprosentasekan sebesar 66,11 persen pada tahun 2001 dan pada tahun 2008 nilai ekspor masih didominasi oleh sektor industri barang kayu dan mebel senilai 2.856,40 milyar rupiah atau sebesar 71,96 persen. Loebis dan Schmitz (2005) menyatakan bahwa industri mebel kayu adalah salah satu industri yang sanggup bertahan ketika terjadi krisis ekonomi tahun 1997, hal ini diketahui dari pertumbuhan industri mebel kayu Jepara dan peningkatan penyerapan tenaga kerja.

Nilai impor Kabupaten Jepara dilihat dari tabel I - O Kabupaten Jepara tahun 2001 dan 2008, terjadi pergeseran yang sangat besar hingga yang mulanya tahun 2001 Jepara masih mengalami surplus perdagangan dilihat dari nilai net ekspor yang masih positif, pada perhitungan data $\mathrm{I}$ - O tahun 2008 terjadi minus perdagangan Kabupaten Jepara. 
Melihat maraknya arus perdagangan ekspor impor Kabupaten Jepara, menarik untuk melihat kembali filosofi kehidupan perekonomian masyarakat Jepara. Jepara berasal dari kata Ujung Para, Ujung Mara dan Jumpara yang kemudian menjadi Jepara. Dilihat dari asal katanya, Jepara berarti sebuah tempat pemukiman pedagang yang berniaga ke berbagai daerah. (Wikipedia bahasa Indonesia, ensiklopedia bebas, diakses tanggal 03 Juni 2015). Hal ini memberikan wawasan karakteristik masyarakat Kabupaten Jepara yang berdasar sejarahnya adalah masyarakat pedagang.

Pengembangan metode analisis perekonomian suatu daerah penting dipakai sebagai pedoman untuk menentukan tindakan-tindakan apa yang harus diambil untuk mempercepat laju pertumbuhan daerah tersebut (Tarigan, 2005:46). Melihat karakteristik masyarakat, wilayah dan perekonomian Kabupaten Jepara, penelitian ini bermaksud melihat gambaran penerapan model basis ekspor pada Kabupaten Jepara.

\section{REVIEW LITERATUR DAN HIPOTESIS}

\section{Teori Pertumbuhan Ekonomi Regional}

Menurut Boediono (1981) (Dalam Robinson Tarigan, 2007 : 46) mengatakan bahwa pertumbuhan ekonomi regional adalah proses kenaikan output perkapita dalam jangka panjang. Pertumbuhan ekonomi berkaitan dengan kenaikan output perkapita dimana ada dua sisi yang perlu diperhatikan, yaitu sisi output totalnya (GDP) dan sisi jumlah penduduknya. Output per kapita adalah output total dibagi dengan jumlah penduduk. Jadi persentase pertumbuhan output itu harus lebih tinggi dari persentase pertambahan jumlah penduduk dan kecenderungan dalam jangka panjang bahwa pertumbuhan itu akan berlanjut.

Menurut Sjafrizal (2008:86) perhatian terhadap pertumbuhan ekonomi daerah semakin meningkat di daerah otonomi daerah ini. Hal ini dipandang sangat logis, karena dalam era otonomi masing-masing daerah berlomba-lomba meningkatkan pertumbuhan ekonomi daerahnya guna meningkatkan kemakmuran masyarakatnya.

\section{Teori Pertumbuhan Ekonomi Regional Basis Export (Export-Base Model)}

Menurut model ini, pertumbuhan ekonomi suatu daerah adalah ditentukan oleh keuntungan kompetitif (competitive advantage) yang dimiliki daerah bersangkutan. Bila daerah yang bersangkutan dapat mendorong pertumbuhan sektor-sektor yang mempunyai keuntungan kompetitif sebagai basis untuk ekspor, maka pertumbuhan daerah yang bersangkutan akan dapat ditingkatkan. Hal ini akan menjadi peningkatan ekspor tersebut dan memberikan dampak berganda multffiplier effect kepada perekonomian daerah.

Menurut Blair yang dikutip oleh Sjafrizal (2008 : 87-88) model basis ini dapat diformulasikan dengan menggunakan formal income model. Dalam model ini PDRB suatu daerah dapat diungkapkan sebagai berikut :

$$
\mathbf{Y}=\mathbf{C}+\mathbf{M}_{\mathbf{1}}-\mathbf{M}_{\mathbf{0}}
$$

Di mana $\mathrm{Y}$ adalah Pendapatan Regional (PDRB), $\mathrm{C}$ adalah konsumsi, $\mathrm{M}_{1}$ adalah menunjukkan arus uang masuk karena adanya ekspor dan $\mathrm{M}_{0}$ adalah arus uang keluar karena adanya import. Untuk kemudahan fungsi konsumsi dalam hal ini dianggap linier, sehingga dapat ditulis:

$$
\mathbf{C}=\mathbf{A}+\mathbf{b} \mathbf{Y}
$$

Dimana A adalah konsumsi minimum dan b menunjukkan marginal Propensity to Consume (MPC)

\section{Asumsi Teori Basis Ekspor}

Teori basis ekspor membuat asumsi pokok bahwa ekspor adalah satu-satunya unsur -unsur eksogen (independen) dalam pengeluaran. Artinya, semua unsur pengeluaran lain terikat (dependen) terhadap pendapatan. Secara tidak langsung hal ini berarti di luar pertambahan 
alamiah, hanya peningkatan ekspor saja yang dapat mendorong peningkatan pendapatan daerah, karena sektor -sektor lain terikat peningkatannya oleh peningkatan pendapatan daerah. Sektor lain hanya meningkat apabila pendapatan daerah secara keseluruhan meningkat. Jadi, satu-satunya yang dapat meningkat secara bebas adalah ekspor. Ekspor terikat di dalam siklus pendapatan daerah. Asumsi kedua ialah bahwa fungsi pengeluaran dan fungsi impor bertolak dari titik nol sehingga tidak akan berpotongan (intercept).

\section{Manfaat Teori Basis Ekspor}

1. Dapat memahami perubahan-perubahan yang terjadi dalam perekonomian suatu wilayah (region).

2. Economic Base Multiplier berguna untuk melakukan evaluasi atau estimasi terhadap dampak pengembangan atau pendirian baru suatu industri di suatu wilayah.

3. Hasil perhitungan Economic Base dapat dipakai sebagai dasar estimasi untuk mengisi gap dalam data historis apabila informasi yang tersedia hanya sebagian.

\section{Kelemahan Teori Basis Ekspor}

Beberapa kelemahan teori basis ekspor adalah sebagai berikut:

1. Menurut Richardson besarnya basis ekspor adalah fungsi terbalik dari besarnya suatu daerah. Artinya, makin besar suatu daerah maka ekspornya akan semakin kecil apabila dibandingkan dengan total pendapatan.

2. Ekspor jelas bukan satu-satunya faktor yang dapat meningkatkan pendapatan daerah. Ada banyak unsur lain yang dapat meningkatkan pendapatan daerah seperti: pengeluaran atau bantuan pemerintah pusat, investasi, dan peningkatan produktivitas tenaga kerja.

3. Dalam melakukan studi atas satu wilayah, multiplier basis yang diperoleh adalah rata-ratanya dan bukan perubahannya. Menggunakan multiplier basis rata-rata untuk proyeksi seringkali memberikan hasil yang keliru apabila ada tendensi perubahan nilai multiplier dari tahun ke tahun.

4. Beberapa pakar berpendapat bahwa apabila pengganda basis digunakan sebagai alat proyeksi maka masalah time lag (masa tenggang) harus diperhatikan.

5. Ada kasus dimana suatu daerah yang tetap berkembang pesat meski ekspornya relatif kecil. Pada umumnya hal ini dapat terjadi pada daerah yang terdapat banyak ragam kegiatan dan satu kegiatan saling membutuhkan dari produk kegiatan lainnya. Pada daerah ini tetap tercipta pasar yang tertutup tetapi dinamis, dan ini bisa terjadi apabila syaratsyarat keseimbangan yang dituntut dalam teori Harrod-Domar dapat dipenuhi.

\section{METODE PENELITIAN}

\section{Variabel yang Digunakan}

Dua variabel utama dalam penelitian ini, memiliki definisi operasional variabel sebagai berikut:

a. Pendapatan Regional yang dihitung melalui PDRB harga konstan (Y)

Secara umum, PDRB didefinisikan sebagai jumlah nilai tambah yang dihasilkan oleh seluruh unit usaha dalam suatu wilayah/ region tertentu dalam kurun waktu tertentu (satu tahun), atau merupakan jumlah seluruh nilai barang dan jasa akhir yang dihasilkan oleh seluruh unit ekonomi di suatu wilayah/ region tertentu dalam kurun waktu tertentu (satu tahun) (BPS, Jawa Tengah).

b. Ekspor (E) dan Impor (M)

Ekspor dan impor barang dan jasa adalah transaksi ekonomi antara penduduk suatu daerah dengan penduduk luar daerah. Transaksi ekspor meliputi pembelian langsung di pasar domestik oleh penduduk daerah lain, sedangkan transaksi impor meliputi pembelian langsung di pasar luar daerah oleh penduduknya. Dalam perhitungan PDRB, yang termasuk ekspor dalam penilitian ini 
mencakup semua pembelian langsung di wilayah Kabupaten Jepara oleh penduduk di luar Kabupaten Jepara. Sementara impor mencakup semua pembelian langsung oleh penduduk di Kabupaten Jepara dari pasar di luar Kabupaten Jepara (Sumber : Tabel I-O Kabupaten Jepara).

Sesuai dengan karakteristik regional, penyusunan ekspor dan impor pada tingkat kabupaten tidak dapat diperlakukan seperti pada tabel input output Jawa Tengah. Pada tabel input output kabupaten Jepara ekspor dan impor barang dan jasa terdiri dari ekspor antar darat dan luar negeri. Data yang digunakan dalam penyusunan ekspor khususnya ekspor luar negeri bersumber dari laporan ekspor dari dinas perindustrian dan perdagangan dan laporan lainnya. Khusus untuk ekspor dan impor melalui darat, seperti ekspor dan impor barang dan jasa dari dan keluar kabupaten Jepara, menggunakan pendekatan penyeimbang antara penyediaan (supply) dan permintaan (demand) sebagai syarat dalam penyusunan tabel input output suatu kabupaten (Sumber: Tabel I-O Kabupaten Jepara).

\section{Jenis Data}

Penelitian ini menggunakan data sekunder dengan periode pengamatan tahun 2004 - 2009. Data-data ini diperoleh dari berbagai penerbitan yangdikeluarkan oleh Badan Pusat Statistik Provinsi Jawa Tengah dan Kabupaten Jepara,Dinas perindustrian dan perdagangan Kabupaten Jepara dari kantor atau dinas yang terkait dengan penelitian ini. Adapun data sekunder dikumpulkan dari berbagai publikasi statistik daerah yang telah tersedia. Publikasi statistik yang dimaksud antara lain adalah:

-Data Kabupaten Jepara Dalam Angka 2010

-Tabel I - O Jepara Tahun 2001

-Tabel I - O Jepara Tahun 2008

-PDRB Kabupaten Jepara Tahun 2010

\section{Metode Pengumpulan Data}

Metode pengumpulan data dan informasi yang berhubungan dengan masalah yang akan dibahas dalam penelitian ini menggunakan metode dokumentasi yaitu pengumpulan data dan informasi dilakukan dengan cara membaca, memahami dan mempelajari buku-buku terbitan Pemerintah Provinsi Jawa Tengah, Pemerintah Kabupaten Jepara seperti Biro Pusat Statistik, artikel-artikel, jurnal-jurnal, dan buku-buku yang mempunyai relevansi dengan masalah yang diangkat dalam penelitian ini, yang diperoleh melalui perpustakaan dan download internet.

\section{Teknik Analisis}

Analisis yang digunakan dalam penelitian ini adalah analisis deskriptif mencakup deskripsi beberapa variabel yang dijabarkan dalam penelitian ini. Analisis deskriptif ini antara lain mengulas mengenai pertumbuhan dan peranan variabel ekspor- impor sebagai faktor penentu dalam teori pertumbuhan regional basis ekspor. Analisis diskriptif ini terlebih dahulu dibangun dari hasil analisis model-model perhitungan yang digunakan, mencakup ; model analisis basis ekspor dan model analisis sektor basis

\section{Model Analisis Basis Ekspor}

Mengacu pada landasan teori yang digunakan, faktor permintaan memegang peran yang sangat sentral dalam pertumbuhan ekonomi regional. Hal ini berangkat dari pemahaman bahwa perekonomian lokal perlu untuk terus menambah aliran uang masuk agar perekonomian mengalamipertumbuhan, sementara atu-satunya cara yang paling efektif untuk menambah aliran uang masuk adalah dengan menambah ekspor. Hal ini berarti ekspor yang merupakan permintaan ekternal terhadap produk lokal menjadi pendorong utama pertumbuhan ekonomi regional (Blair, 1991, Hoover, 1984). Teori basis ekspor dapat diformulasikan sebagai berikut 
$\Delta Y=k \Delta X$

Dimana :

Y adalah output/pendapatan/tenaga kerja

$\mathrm{X}$ adalah ekspor

$\mathrm{k}$ adalah angka pengganda

Asumsi pokok pada teori basis ekspor bahwa ekspor adalah satu-satunya unsur -unsur eksogen (independen) dalam pengeluaran. Asumsi kedua adalahfungsi pengeluaran dan fungsi impor bertolak dari titik nol sehingga tidak mungkin akan berpotongan (intercept). Berkenaan dengan suatu daerah (i) dapat diformulasikan sebagai berikut :

$\mathrm{Y}_{\mathrm{i}}=\left(\mathrm{E}_{\mathrm{i}}-\mathrm{M}_{\mathrm{i}}\right)+\mathrm{X}_{\mathrm{i}}$

Pendapatan pengeluaran untuk barang / jasa domestik ekspor, dimana :

$$
\begin{array}{ll}
\mathrm{E}_{\mathrm{i}} & =\mathrm{e}_{\mathrm{i}} \mathrm{Y}_{\mathrm{i}} \ldots \ldots \ldots \ldots \ldots . . . . . \\
\mathrm{M}_{\mathrm{i}} & =\mathrm{m}_{\mathrm{i}} \mathrm{Y}_{\mathrm{i}} \ldots \ldots \ldots \ldots \ldots \\
\mathrm{X}_{\mathrm{i}} & \mathrm{X} \text { (eksogen)... }
\end{array}
$$

Dimana :

$\mathrm{e}_{\mathrm{i}}=$ Marginal Propensity to Expenditure (hasrat membelanjakan uang)

$\mathrm{m}_{\mathrm{i}}$ = Marginal Propensity to Import (hasrat membeli barang impor)

Dengan mensubtitusi fungsi - fungsi (3), (4), dan (5) ke dalam persamaan no (2)

Maka, $\mathrm{Y}_{\mathrm{i}}=\mathrm{e}_{\mathrm{i}} \mathrm{Y}_{\mathrm{i}}-\mathrm{m}_{\mathrm{i}}+\mathrm{X}_{\mathrm{i}}$ dengan demikian

$Y_{i}=\frac{\frac{1}{x_{1}}}{1-e_{i}+m_{i}}$

Jika fungsi no (2.6) diubah susunanya maka :

$\frac{Y_{i}}{\overline{x_{i}}}=\frac{1}{1-e_{i}+m_{i}}$

$\frac{Y_{i}}{-}$ adalah rasio pendapatan terhadap ekspor yang disebut multipier basis yang diberi simbol K.

$\mathrm{K}=\frac{1}{1-\varepsilon_{i}+m_{i}}$
Dapat disimpulkan, pendapatan regional adalah kelipatan dari ekspor. Ketika hasrat membelanjakan secara lokal (e-m) adalah lebih kecil daripada satu, akan mendapatkan hasil multiplier basis rata-rata. Proyeksi menggunakan perubahan pendapatan akibat perubahan atas eksport $\left(\frac{\Delta Y_{i}}{\Delta X_{i}}\right)$. Dalam kasus besarnya multiplier basis secara rata-rata sama dengan besarnya $\frac{\Delta Y_{i}}{\Delta X_{i}}$ , maka hasil $\mathrm{K}$ tersebut dapat digunakan sebagai alat peramalan/ proyeksi. (Tarigan, 2005 : 57).

\section{Model Analisis Sektor Basis}

Sektor basis suatu daerah akan menjadi sektor pendorong besarnya ekspor regional. MenurutArief(1993), Penelitian ini menggunakan indeks keterkaitan kedepan dan kebelakang untuk menentukan sektor basis, sedangkan untuk mengidentifikasi kaitan kebelakang (backward lingkage) dan kaitan kedepan (forward linkage), maupun komposisi permintaan akhir digunakan analisis terhadap tabel Input - Output.

\section{-Analisis Input Output}

Metode analisis I-O yang digunakan dalam penulisan ini, adalah analisis diskriptif atau yang dikenal juga dengan analisis tabel dasar, dan (2) analisis keterkaitan/ analisis dampak yaitu analisis data dengan menggunakan matriks inverse leontief. Analisis diskriptif dilakukan atas tabel dasar I-O. Tabel dasar I-O Kabupaten Jepara yang tersedia sampai tahun 2015 ini adalah tabel I-Omultiregional tahun 2001 dan 2008. Tabel ini menyajikan informasi statistik yangmemuat gambaran mengenai besarnya nilai transaksi barang dan jasa antar sektor ekonomi di kabupaten Jepara. Beberapa variabel atau indikator yang dianalisis dalam tabel tersebut yaitu : (a) Struktur penawaran dan permintaan output; (b) Struktur output lokal dandomestik; (c) Struktur nilai tambah bruto (PDRB); (d) Struktur permintaan akhir (final demand), dan perdagangan (ekspor dan impor) antar wilayah. 


\section{Analisis Data dengan Matriks Inverse Leontief Indeks Total Keterkaitan ke Belakang}

Konsep indeks total keterkaitan ke belakang menunjukkan kemampuan suatu sektor untuk meningkatkan pertumbuhan industri hulunya. Indeks total keterkaitan kebelakang disebut sebagai indeks daya penyebaran (power ofdispersion). Rumus untuk mencari nilai indeks total keterkaitan ke belakang yaitu :

$\operatorname{Bdj}=\sum_{i=1}^{n}$ aij

Dimana :

$B=$ backward, $\mathrm{d}=$ direct, $\mathrm{j}=$ kolom ke- $\mathrm{j}, \mathrm{i}=$ baris ke i

aij $=$ koefisien input yang merupakan elemen matriks A

Efek ke belakang langsung dan tidak langsung adalah penjumlahan kolom matriks(I-A) -1 , atau matriks kebalikan input atau matriks kebalikan Leontief.

$b d+i d=\sum_{i=1}^{n} \alpha \mathrm{ij}$.

Dimana :

$\mathrm{B}=$ backward, $\mathrm{d}=$ direct, $\mathrm{id}=$ indirect, $\mathrm{j}=$ kolom ke j, $\mathrm{i}=$ baris ke I, dan $\alpha \mathrm{ij}=$ elemen matriks (I-A ) -1. Dari rumus10, keterkaitan total adalah sama dengan angka pengganda output.

- $\operatorname{BLj}=1$, berarti daya penyebaran sektor $\mathrm{j}$ sama dengan rata-rata penyebaran seluruh sektor ekonomi.

- $\quad B L j>1$, berarti daya penyebaran sektor $\mathrm{j}$ berada di atas rata-ratadaya penyebaran seluruh sektor ekonomi.

- $\quad B L j<1$ berarti daya penyebaran sektor $\mathrm{j}$ lebih rendah dari rata -rata daya penyebaran seluruh sektor ekonomi.

\section{Indeks Total Keterkaitan ke Depan}

Indeks total keterkaitan ke depan merupakan gambaran kemampuan suatu sektor dalam mendorong pertumbuhan produksi sektor-sektor lain dimana sektor-sektor lain memakai sektor tersebut sebagai input. Indeks total keterkaitan ke depan disebut juga sebagai indeksderajat kepekaan (degree of sensitivity).

Rumus untuk mencari nilai indeks total keterkaitan ke depan yaitu :

$F d i=\sum_{j=1}^{n} \alpha \mathrm{ij}$.

Dimana :

$\mathrm{F}=$ forward, $\mathrm{d}=$ direct, $\mathrm{id}=$ indirect, $\mathrm{j}=$ kolom ke $\mathrm{j}, \mathrm{i}=$ baris ke I, $\alpha \mathrm{ij}=$ elemen matriks (I-A)-1

Dari persamaan 11 diketahui indeks keterkaitan ke depan sama dengan angka pengganda input.

- Bila Fdi = 1 hal tersebut berarti bahwa derajat kepekaan sektor Isama dengan rata-rata derajat kepekaan seluruh sektor ekonomi.

- Bila FLi >1 hal tersebut berarti derajat kepekaan sektor i lebih tinggi dari derajat kepekaan seluruh sektor ekonomi.

Bila FLi $<1$ hal tersebut berarti bahwa derajat kepekaan sektor i dibawah rata-rata derajat kepekaan seluruh sektor ekonomi.

\section{HASIL PENELITIAN DAN PEMBAHASAN}

\section{Gambaran Geografis Wilayah}

Secara geografis Kabupaten Jepara terletak pada posisi $110^{\circ} 9^{\prime} 48,02^{\prime \prime}$ sampai $110^{\circ}$ $58^{\prime} 37,40^{\prime \prime}$ Bujur Timur, 5० 43' 20,67" sampai $6^{\circ} 47^{\prime} 25,83^{\prime \prime}$ Lintang Selatan. Kabupaten ini merupakan daerah paling ujung sebelah utara dari Provinsi Jawa Tengah. Batas barat dan utara Kabupaten Jepara adalah Laut Jawa, batas timur Kabupaten Jepara adalah Kabupaten Pati, serta barat selatannya adalah Kabupaten Demak. 
Kabupaten Jepara memiliki luas wilayah daratan 1.004,189 $\mathrm{km}^{2}$ dengan panjang garis pantai $72 \mathrm{~km}$. Wilayah Kabupaten Jepara juga mencakup luas lautan sebesar $1.845,6 \mathrm{~km}^{2}$. Secara administratif wilayah seluas $1.004,132 \mathrm{~km}^{2}$ tersebut terdiri atas 16 kecamatan yang dibagi lagi atas sejumlah 194 desa dan 11 kelurahan. Pada wilayah lautan terdapat daratan kepulauan sejumlah 29 pulau, dengan 5 pulau berpenghuni dan 24 pulau tidak berpenghuni.

Wilayah tersempit di Kabupaten Jepara adalah Kecamatan Kalinyamatan $\left(24,179 \mathrm{~km}^{2}\right)$ sedangkan wilayah terluas adalah Kecamatan Keling $\left(231,758 \mathrm{~km}^{2}\right)$. Sebagian besar luas wilayah merupakan tanah kering, sebesar $740,052 \mathrm{~km}^{2}(73,70 \%)$ sisanya merupakan tanah sawah, sebesar 264,080 $\mathrm{km}^{2}(26,30 \%)$. Wilayah kepulauan Jepara juga mencakup Kecamatan Karimunjawa. Kecamatan Karimunjawa berada di gugusan Kepulauan Karimunjawa, yakni gugusan pulau-pulau yang ada di Laut Jawa dengan dua pulau terbesarnya adalah Pulau Karimunjawa dan Pulau Kemujan (Sumber: http://www.jeparakab.go.id/, diakses tanggal 27 Mei 2015).

\section{Gambaran Umum Perekonomian}

Secara umum Kabupaten Jepara dikenal sebagai kota ukir, karena terdapat sentra kerajinan ukiran kayu ketenarannya hingga ke luar negeri. Kerajinan mebel dan ukir ini tersebar merata hampir di seluruh kecamatan dengan keahlian masing-masing. Industri Mebel Ukir Jepara tersebar di semua kecamatan Jepara, kecuali Kecamatan Karimunjawa (Sumber: Wikipedia bahasa Indonesia, ensiklopedia bebas, diakses tanggal 27 Mei 2015).

\section{Struktur Perekonomian}

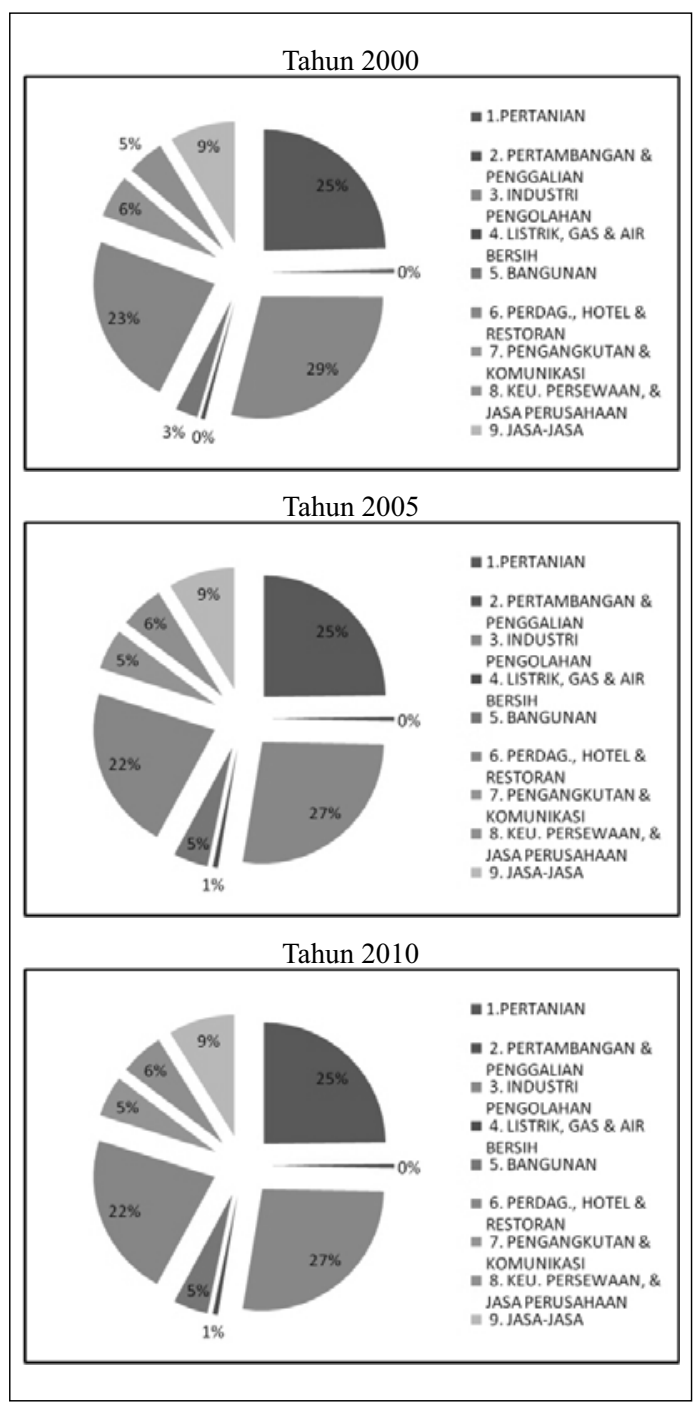

Sumber : PDRB Kabupaten Jepara, BPS 2010, diolah Gambar 1

Struktur Perekonomian Kabupaten Jepara Atas Dasar Harga Konstan 2000 Tahun 2000, 2005 dan 2010 (Juta Rupiah)

Struktur perekonomian Kabupaten Jepara pada tahun 2000, 2005, 2010 menunjukan tidak telalu banyak perubahan selama tahun tersebut sektor industri pengolahan menjadi sektor yang paling dominan dan memberikan kontribusi paling tinggi terhadap PDRB Kabupaten Jepara yaitu sebesar $29 \%$ pada tahun $2000,27 \%$ tahun 2005 dan 28\% tahun 2010,selain sektor industri 
pengolahan ada 2 sektor lagi yang memberikan kontribusi cukup besar yaitu sektor pertanian dan perdagangan, hotel dan restoran, sedangkan sektor-sektor yang lain hanya memberikan kontribusi yang tidak terlalu besar. Sektor industri pengolahan sendiri tersusun 85 persennya dari Industri barang kayu dan hasil hutan lainnya yang besarnya tidak perubah dari tahun 2000, 2005 dan 2010. (lihat gambar 2)

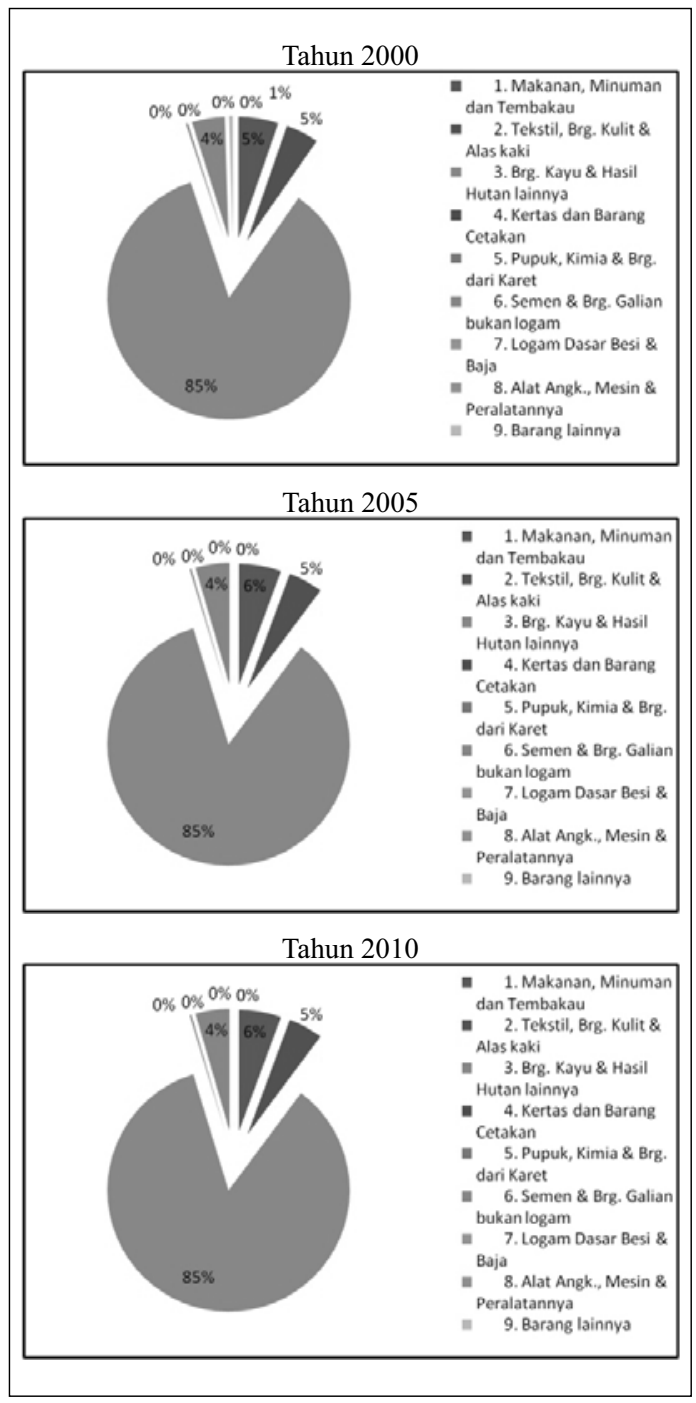

Sumber : PDRB Kabupaten Jepara, BPS 2010, diolah

Gambar 2

Komposisi Industri Pengolahan Kabupaten Jepara

Atas Dasar Harga Konstan 2000 Tahun 2000, 2005 dan 2010 (Juta Rupiah)
Karakteristik Perekonomian Kabupaten Jepara Terkait dengan Teori Pertumbuhan Regional Basis Ekspor

Aktivitas perekonomian regional dalam model pertumbuhan basis ekspor digolongkan dalam dua sektor kegiatan yakni aktivitas basis dan non basis. Aktivitas ekonomi basis merupakan kegiatan ekonomi yang orientasinyai mengekspor barang dan atau jasa ke luar wilayah yang bersangkutan. Aktivitas ekonomi non-basis adalah kegiatan yang orientasinya menyediakan barang dan jasa yang dibutuhkan oleh masyarakat yang berada di dalam batas wilayah perekonomian yang bersangkutan. Luas lingkup produksi dan pemasarannya adalah bersifat lokal.

\section{Derajat Penyebaran dan Derajat Kepekaan}

Derajat penyebaran digunakan untuk melihat keterkaitan ke belakang (backward linkages)sektor-sektor ekonomi dalam suatu wilayah.Jumlah derajat penyebaran ini menunjukkan dampak dari perubahan permintaan akhir suatu sektor terhadap output seluruh sektor ekonomi suatu wilayah. Suatu sektor dikatakan memiliki DP yang tinggi bila pertumbuhan sektor tersebut sangat mempengaruhi sektor-sektor lainnya. DP $>1$ berarti daya penyebaran sektor $\mathrm{j}$ berada di atas rata-rata daya penyebaran seluruh sektor ekonomi.Sedangkan Derajat kepekaan merupakan suatu ukuran yang memperlihatkan besarnya output yang harus disediakan oleh suatu sektor untuk satu unit perubahan permintaan akhir terhadap sektor perekonomian. Derajat kepekaan (DK) digunakan untuk melihat keterkaitan ke depan (forward linkages).Suatu sektor dikatakan peka bila mempunyai reaksi yang cepat terhadap keseluruhan pertumbuhan perekonomian. DK> 1 berarti derajat kepekaan sektor $\mathrm{j}$ berada di atas rata-rata daya penyebaran seluruh sektor ekonomi.

Sektor-sektor ekonomi yang memiliki DP dan DK lebih besar dari 1 adalah sektor-sektor unggulan (leading sector) di suatu wilayah. Sektor - sektor dengan nilai DP dan DK lebih 
dari satu pada Kabupaten Jepara ditunjukkan oleh tabel 3. dan 4.Menyoroti pada sektor industri kayu, pada tahun 2001 dan 2008 sektor tersebut tetap merupakan sektor unggulan, namun terjadi peningkatan indeks di tahun 2008. Sektor industri kayu menjadi sektor dengan nilai tertinggi untuk DP dan DK-nya. Pada tahun 2008 sektor ini menjadi lebih peka/ memiliki reaksi yang lebih cepat terhadap pertumbuhan perekonomian keseluruhan dan juga pertumbuhan sektor ini memiliki dampak/ pengaruh yang lebih besar terhadap sektor - sektor lainnya.

\section{Tabel 3}

\section{Sektor yang Memiliki Derajat Penyebaran dan Derajat Kepekaan Lebih dari 1 Kabupaten Jepara Tahun 2001}

\begin{tabular}{|c|l|c|c|}
\hline \multirow{2}{*}{ KODE } & \multicolumn{1}{|c|}{ SEKTOR } & \multicolumn{2}{|c|}{ KOEFISIEN } \\
\hline & \multicolumn{1}{|c|}{$(2)$} & DP & DK \\
\hline$(1)$ & \multicolumn{1}{|c|}{$(3)$} & $(4)$ \\
\hline 18 & $\begin{array}{l}\text { Industri makanan dan } \\
\text { minuman }\end{array}$ & 1,3663 & 1,1828 \\
\hline 20 & $\begin{array}{l}\text { Industri tekstil dan pakaian } \\
\text { jadi }\end{array}$ & 1,4582 & 1,5807 \\
\hline 21 & $\begin{array}{l}\text { Industri kayu dan bahan } \\
\text { bangunan dari kayu }\end{array}$ & 1,1217 & 1,1401 \\
\hline 27 & Listrik, gas dan air minum & 1,1098 & 1,0101 \\
\hline 28 & Bangunan & 1,1083 & 1,1401 \\
\hline 31 & Angkutan jalan raya & 1,0239 & 1,4449 \\
\hline
\end{tabular}

Sumber : Tabel I-O Jepara, 2001, diolah

Tabel 4

Sektor yang Memiliki Derajat Penyebaran dan Derajat Kepekaan Lebih dari 1 Kabupaten Jepara Tahun 2008

\begin{tabular}{|l|l|c|c|}
\hline \multirow{2}{*}{ KODE } & \multicolumn{1}{|c|}{ SEKTOR } & \multicolumn{2}{|c|}{ KOEFISIEN } \\
\hline & & DP & DK \\
\hline$(1)$ & \multicolumn{1}{|c|}{$(2)$} & $(3)$ & $(4)$ \\
\hline 18 & $\begin{array}{l}\text { Industri tekstil \& } \\
\text { pakaian jadi }\end{array}$ & 1,3649 & 1,2366 \\
\hline 19 & $\begin{array}{l}\text { Industri barang } \\
\text { kayu \& meubel }\end{array}$ & 1,4711 & 1,2981 \\
\hline 22 & $\begin{array}{l}\text { Listrik, gas \& air } \\
\text { minum }\end{array}$ & 1,2535 & 1,0187 \\
\hline 23 & Bangunan & 1,0681 & 1,2497 \\
\hline 25 & $\begin{array}{l}\text { Hotel \& rumah } \\
\text { makan }\end{array}$ & 1,1216 & 1,1750 \\
\hline 26 & Angkutan & 1,0127 & 1,1807 \\
\hline
\end{tabular}

Sumber : Tabel I - O Jepara, 2008, diolah

\section{Permintaan Akhir}

Setiap permintaan akhir akan merangsang peningkatan output, yang selanjutnya akan meninmbulkan peningkatan nilai tambah. Permintaan akhir secara umum terdiri atas (1) konsumsirumah tangga, (2) konsumsi pemerintah, (3) pembentukan modal, (4) perubahan stok dan (5) ekspor.

Dilihat dari komponennya, pada tahun 2001 maupun 2008, komponen ekspor memiliki pengaruh terbesar dibanding komponen lainnya dalam penciptaan output. Pada tahun 2001 komponen impor juga sebagai komponen yang permintaannya paling besar memberikan pengaruh terhadap nilai tambah, namun pada tahun 2008, komponen konsumsi rumah tangga lah yang perngaruh permintaannya terhadap nilai tambah paling besar, sedangkan ekspor menempati urutan ke dua setelahnya.

Tabel 5

\section{Komponen Permintaan Akhir Kabupaten Jepara Tahun 2001}

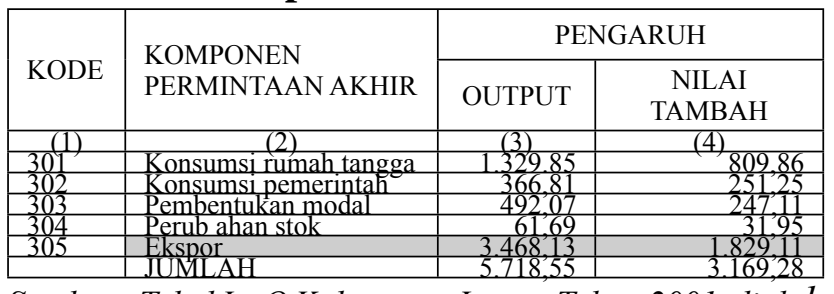

Sumber : Tabel I-O Kabupaten Jepara Tahun 2001, diolah

\section{Tabel 6}

\section{Komponen Permintaan Akhir Kabupaten} Jepara Tahun 2008

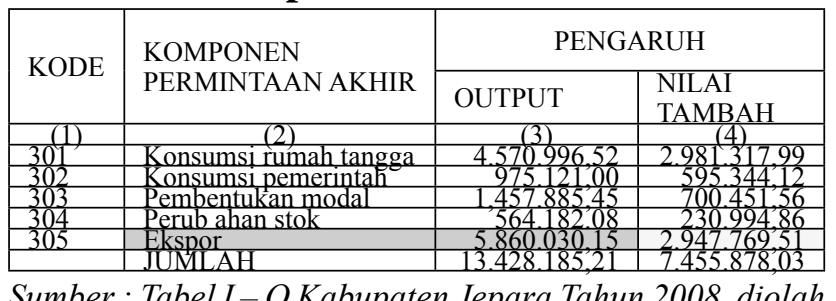

Sumber : Tabel I-O Kabupaten Jepara Tahun 2008, diolah 
Gambaran Penerapan Teori Pertumbuhan Basis Ekspor pada Kabupaten Jepara

\section{Angka Pengganda Ekspor 2001}

Tabel 7

PDRB Penggunaan Kabupaten Jepara Tahun 2001 (Jutaan Rupiah)

\begin{tabular}{|l|r|}
\hline Keterangan & \multicolumn{1}{c|}{ Tahun 2001 } \\
\hline Konsumsi (RT dan Pemerintah) & $2.478 .320,05$ \\
\hline Investasi (PMTB + Perubahan Stok) & $533.173,72$ \\
\hline Ekspor & $2.461 .557,08$ \\
\hline Impor & $1.907 .768,09$ \\
\hline PDRB Penggunaan & $3.565 .282,76$ \\
\hline
\end{tabular}

Sumber : Tabel I - O Kabupaten Jepara Tahun 2001, diolah.

Dari tabel 7 dapat dihitung angka pengganda ekspor tahun $2 \mathrm{n}_{Y_{i}} 01$,

$$
\mathrm{K}=\frac{Y_{i}}{\bar{x}_{i}} \text {, }
$$

$\mathrm{K}=3.565 .282,76 / 2.461 .557,08$

$$
\mathrm{K}=1,45
$$

Angka Pengganda Ekspor 2008

Tabel 8

PDRB Penggunaan Kabupaten Jepara Tahun 2008 (Jutaan Rupiah)

\begin{tabular}{|l|c|}
\hline Keterangan & Tahun 2008 \\
\hline Konsumsi (RT dan Pemerintah) & $6.682 .723,38$ \\
\hline Investasi (PMTB + Perubahan Stok) & $1.594 .557,13$ \\
\hline Ekspor & $4.381 .659,44$ \\
\hline Impor & $5.203 .061,92$ \\
\hline PDRB Penggunaan & $7.455 .878,03$ \\
\hline
\end{tabular}

Sumber : Tabel I - O Kabupaten Jepara Tahun 2008, diolah.

Dari tabel 8 dapat dihitung angka pengganda ekspor tahun 2008 ,

$$
\mathrm{K}=\frac{Y_{i}}{\bar{x}_{i}},
$$

$\mathrm{K}=7.455 .878,03 / 4.381 .659,44$

$$
\mathrm{K}=1,70
$$

\section{Perubahan Angka Pengganda Ekspor}

Perubahan angka pengganda ekspor diasumsikan sepanjang 2001 hingga 2008 tidak terjadi perubahan angka pengganda yang berarti.

$$
\frac{\Delta Y_{i}}{\Delta X_{i}}=\text { perubahan multiplier basis }
$$

Perubahan angka pengganda ekspor = $3.590 .595,27 / 1.920 .102,36=2,03$

Hasil perhitungan angka pengganda ekspor tahun 2008 menunjukkan hasil yang lebih besar dibanding tahun 2001, demikian juga dengan perubahan angka pengganda ekspor yang menunjukkan nilai7 yang lebih besar dibanding angka pengganda ekspor tahun 2001 maupun 2008. Hal ini mengindikasikan terjadi kemajuan peran ekspor dengan tetap memperhatikan segala kondisi lainnya yang terlah diuraikan, sehingga model basis ekspor dapat untuk diaplikasikan dengan memperkuat basis ekspor, terkhusus pada industri pengolahan barang kayu. Kemudian bila dikaji lebih jauh didapatkan :

$$
\begin{array}{lc}
\multicolumn{1}{c}{\text { Tahun 2001 }} & \text { Tahun 2008 } \\
\begin{aligned}
\mathrm{e}_{\mathrm{i}}=3.565 .282,76 / 3.011 .493,77 & \mathrm{e}_{\mathrm{i}}=7.455 .878,03 / 8.277 .280,51 \\
=1,18 & =0,90 \\
\mathrm{~m}_{\mathrm{i}}=3.565 .282,76 / 1.907 .768,09 & \mathrm{~m}_{\mathrm{i}}=7.455 .878,03 / 5.203 .061,92 \\
=1,87 & =1,43 \\
\text { Sehingga } \mathrm{e}_{\mathrm{i}}-\mathrm{m}_{\mathrm{i}} \text { lebih kecil dari } & \text { Sehingga } \mathrm{e}_{\mathrm{i}}-\mathrm{m}_{\mathrm{i}} \text { lebih kecil dari } \\
\text { pada satu } & \text { pada satu }
\end{aligned}
\end{array}
$$

nilai $e_{i}-m_{i}$ yang menunjukkan hasrat membelanjakan secara lokal pada tahun 2001 dan 2008 menunjukkan angka yang lebih kecil dari 1 , sehingga pendapatan regional adalah kelipatan dari ekspor.

\section{Gambaran Neraca Perdagangan Kabupaten Jepara Tahun 2001 dan 2008 \\ Pada tahun 2001, nilai ekspor Kabupaten Jepara mencapai 2.465,56 milyar rupiah dengan}


ekspor industri perabot rumah tangga dari kayu 1.630,07 milyar rupiah, jumlah ini sebesar 66,11 persen dari keseluruhan ekspor. Pada tahun tersebut masih terjadi surplus neraca perdagangan sebesar 557,79 milyar rupiah (nilai keseluruhan impor adalah 1.907,77 milyar rupiah) (Sumber :tabel I - O Kabupaten Jepara,2001).

Pada tahun 2008, terjadi pergeseran nilai ekspor- impor yang cukup besar. Neraca perdagangan Kabupaten Jepara menunjukkan nilai impor lebih besar dari ekspor(lihat tabel 9)

\section{Tabel 9}

Kegiatan Ekspor dan Impor Utama

$$
\text { Kabupaten Jepara }
$$

Tahun 2008 (Jutaan Rupiah)

\begin{tabular}{|c|c|c|c|c|c|}
\hline Kode & Sektor Ekspor & Output & Kode & Sektor Impor & Output \\
\hline$\frac{11}{19}$ & Industri barang kayu & $2.856 .401,44$ & $\frac{144}{21}$ & Tndusti barang & $2.096 .831,38$ \\
\hline 4 & $\begin{array}{l}\text { dan mebel } \\
\text { Buah - buahan }\end{array}$ & $326.907,43$ & 17 & Industri & $1.686 .899,67$ \\
\hline & & & & makanan dan & 53112936 \\
\hline 1 & Padi & $276.809,12$ & 13 & $\begin{array}{l}\text { rokok } \\
\text { Kayu dan }\end{array}$ & \\
\hline 9 & Hasil tanaman serat & $249.802,87$ & & hasil hutan & \\
\hline 20 & $\begin{array}{l}\text { Industri mineral non } \\
\text { logam }\end{array}$ & $158.906,14$ & & & \\
\hline & Kacang - kacangan & & & & \\
\hline & Jumlah & $3.969 .206,78$ & & Jumlah & $4.314 .860,41$ \\
\hline & Sektor 1 & $412.452,66$ & & Sektor lainnya & $888.201,51$ \\
\hline & Jumlah 31 sektor & $4.381 .659,44$ & & Jumlah 31 & 5.203.061,92 \\
\hline
\end{tabular}

Sumber : Tabel I - O Jepara, 2008

Tabel 9 menunjukkan nilai ekspor masih didominasi oleh sektor barang kayu, bila diprosentasekan, komposisinya sebesar 71.96 persen. Kondisi impor yang membesar melebihi nilai ekspor menandakan keterbatasan produksi domestik Kabupaten Jepara, Industri barang kayu dan mebel (19) yang merupakan sektor dengan ekspor terbesar, bahan bakunya (kayu dan hasil hutan lainnya (13)) masih harus mengimpor dari luar daerah sebesar 531.129,36 juta rupiah. Besarnya impor juga dipacu oleh tidak tersedianya barang-barang lain (21).Kurang tersedianya bahan baku kayu danhasil hutan lainnya, pada tahun 2011, diperjelas lagi dengan peta tata guna lahan yang menunjukkan sedikitnya daerah hutan (lihat gambar 3).
Gambar 3

Peta Tata Guna Lahan Kabupaten Jepara

Tahun 2011

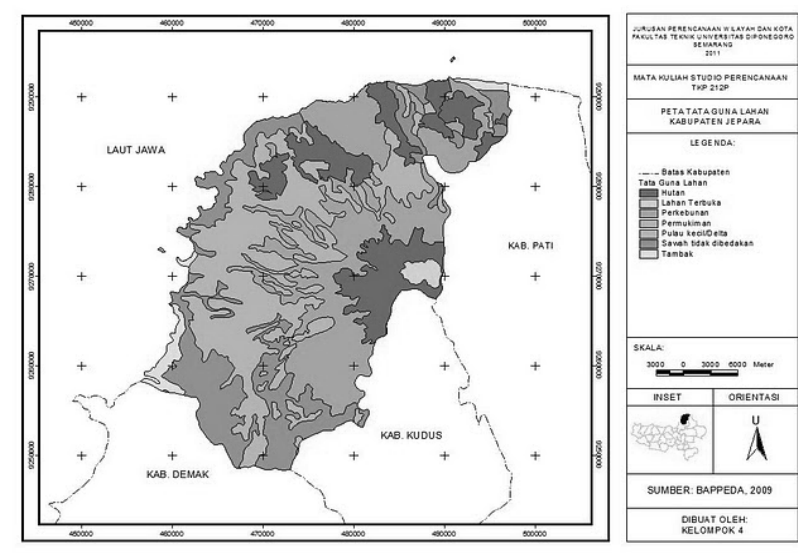

Sumber : https://lh3.googlelisercontent.com/, diakses tanggal 27 Mei 2015

\section{KESIMPULAN DAN SARAN}

\section{Kesimpulan}

1. Kondisi neraca perdagangan Kabupaten Jepara yang mengalami defisit perlu menjadi perhatian bila ingin menerapkan model pertumbuhan basis ekspor menimbang, keunggulan-keunggulan Kabupeten Jepara (karakteristik masyarakat Kabupaten Jepara yang dilihat dari sejarahnya adalah masyarakat pedagang, keahlian kerajinan ukir yang turun-temurun, kemampuan bertahan disaat krisis, serta branding barang mebel dan kerajian ukir) yang sebenarnya dapat dijadikan kekuatan permintaan (ekspor).

2. Peranan komponen ekspor bila dilihat dari pengaruh permintaannya terhadap nilai tambah pada tahun 2008 mengalami penurunan dibanding tahun 2001, namun angka penggandanya adalah lebih besar di tahun 2008. 


\section{Saran}

1. Memperhatikan kelemahan - kelemahan model pertumbuhan regional basis ekspor, dalam penerapannya (bila hendak diterapkan) model basis ekspor di Kabupaten Jepara memerlukan kombinasi dengan model pertumbuhan yang lain.

2. Untuk penelitian yang akan datang dapat melihat membandingkan gambaran penerapan teori pertumbuhan basis ekspor bila diterapkan pada Kabupaten/ Kota lainnya maupun membandingkan dengan penerapan teori pertumbuhan regional lainnya.

\section{DAFTAR PUSTAKA}

Arsyad, Lincolin. 1999. Pengantar Perencanaan dan Pembangunan Ekonomi Daerah. Yogyakarta: BPFE.

Boediono. 1981. Teori Pertumbuhan Ekonomi. Yogyakarta: BPFE.

BPS Kabupaten Jepara. 2010. Produk Domestik Regional Bruto Kabupaten Jepara Tahun 2009.

BPS Kabupaten Jepara. Daerah Dalam Angka Kabupaten Jepara Tahun 2010.

BPS Kabupaten Jepara. Tabel I-O Kabupaten Jepara Tahun 2001.
BPS Kabupaten Jepara. Tabel I-O Kabupaten Jepara Tahun 2008.

BPS Provinsi Jawa Tengah. Daerah Dalam Angka Provinsi Jawa Tengah Tahun 2000 2010.

Hoover, E.M. 1984. Pengantar Ekonomi Regional. Jakarta: Lembaga Penerbit FE UI.

Richardson, H. W. 1977. Dasar-Dasar Ilmu Ekonomi Regional (Terjemahan Paul Sitohang). Jakarta: Lembaga Penerbit FE UI.

Sjafrizal. 2008. Ekonomi Regional Konsep dan Penerapan.

Tarigan, Robinson. 2009. Ekonomi Regional Teori dan Aplikasi. Jakarta: Bumi Aksara.

Wikipedia Bahasa Indonesia. Ensiklopedia bebas: 27 Mei 2015

http://www.jeparakab.go.id/, diakses tanggal 27 Mei 2015

http://studiolproses.files.wordpress.cor2011/03/ jepara-kabupaten1.jpg, diakses tanggal 27 Mei 2015

https://lh3.googlelisercontent.com/, diakses tanggal 27 Mei 2015 